\title{
BREVE INTRODUCCIÓN A LAS NOCIONES DE CIENCIA Y ARTE DE LA MAGIA EN TOMÁS DE AQUINO. DE LA BEATITUD PERSONAL AL RETOR- CIMIENTO ESPIRITUAL
}

\section{A SUMMARY INTRODUCTION TO NOTIONS OF SCIENCE AND MAGIC ART IN THOMAS AQUINAS. FROM THE PER- SONNAL HOLINESS TO SPIRITUAL DISTORT}

\author{
José María Felipe Mendoza ${ }^{1}$ \\ UNCuyo/CONICET, Mendoza - Argentina
}

Recibido: 8-9-2015

Aceptado: 23-11-2015

\begin{abstract}
Resumen: Este artículo indaga la concepción de Tomás de Aquino sobre la 'actividad de la magia' como reverso y retorsión espiritual del estudio de las ciencias. Tal concepción evidencia tres aspectos en lo que hace al enfoque de la cuestión: 1. una prudencia general en el lenguaje y en las referencias a casos concretos que afecta particularmente a los modos de realización de prácticas mágicas; 2 . la necesidad de conocer previamente historia bíblica al tratar el tema de la magia, de modo especial las tretas del demonio y sus secuaces; 3 . la admisión de la predisposición humana, en virtud del pecado original -aunque bajo permisión divina-, de familiarizarse con los demonios. Sobre esta base el texto se organiza en tres partes. La primera atiende a las definiciones de ciencia y filosofía, su fin último y su relación con la Sagrada Escritura. La segunda trae a colación los pasajes más relevantes sobre la magia en general, y finalmente la tercera presenta las traducciones de las escasas veces que Tomás de Aquino se explaya sobre la nigromancia.
\end{abstract}

Palabras claves: Tomás de Aquino; Ciencia; Filosofía; Arte; Magia.

Abstract: This paper gathers information about Thomas Aquinas' viewpoint regarding 'the activity of the magic art' as the reverse side and spiritual distort

1. (josefelipemendoza@hotmail.com) Pertenece al Conicet (Consejo Nacional de Investigación científica y tecnológica de la República Argentina); Investigador del CEFIM (Centro de estudios de Filosofia Medieval - Universidad Nacional de Cuyo, Facultad de Filosofía y Letras). 
of the study of science. This notion of magic has three characteristics in Aquinas. 1. There is a general prudence in the writing style and its references to specific cases that particularly affect the ways in which the magical practices are implemented. 2. The reader is supposed to have some knowledge about biblical history, and especially about the devil's trickery and his supporters. 3. There is human tendency to get acquainted with demons, due to the original sin, though under divine permission. Based on this, the text is organized into three parts. The first part deals with the definitions of science and philosophy, their ultimate aim and their relationship with the Sacred Scripture. The second part brings up the most relevant passages of magic in general, and finally the third part shows the translations of the term 'necromancy' that Thomas Aquinas seldom mentions.

Keywords: Thomas Aquinas, Science, Philosophy, Art, Magic.

Una de las temáticas que actualmente sigue siendo de mayor interés entre los estudiosos y especialistas de la historia medieval y renacentista europea es aquella relativa a la brujería, adivinación, maleficios y una vasta cantidad de artes mágicas. Este mundillo, que se manifiesta como tensión dialéctica entre teólogos y santos de la Iglesia Católica por un lado, y apóstatas de la fe en conjunto con las fuerzas del paganismo por el otro, ha sido analizado desde diferentes disciplinas como la historia, la literatura, la antropología y la pintura. Quizá el ejemplo más paradigmático sea el manual Malleus Maleficarum escrito por los frailes dominicos Heinrich Kramer y Jacobus Sprenger en 1484 d. C. para la identificación y cacería de los magos, en tanto su influencia fue manifiestamente decisiva en los procesos inquisitoriales de las iglesias católicas y protestantes de los siglos siguientes.

Importa destacar este texto en particular porque su circulación conllevaba la divulgación de las opiniones de santos medievales, entre cuyas páginas figuran reiteradas veces Agustín de Hipona y Tomás de Aquino. Y aunque estos teólogos sirvieran de fundamentación doctrinal para los razonamientos de los dominicos Kramer y Sprenger, es también cierto que el fermento de sus ideas arroja un resultado poco feliz si se tiene en cuenta la completa doctrina del Hiponense y el Aquinate. En razón de ello, y según la orientación del presente texto, se pretende ahondar en la visión del propio Tomás con independencia de las citas del Malleus Maleficarum, salvaguardando la doctrina de este dominico del s. XIII en su autenticidad especulativa. La razón de esta finalidad estriba en evidenciar el desconocimiento, por un lado, de la posición cabal del santo, y por el otro, en colaborar con el esclarecimiento de la transición doctrinal del s. XIII al s.

Thémata. Revista de Filosofía №54 (2016) pp.: 149-174. 
$\mathrm{XV}$ entre los frailes dominicos. ${ }^{2}$ A la ausencia de tales conocimientos alude el estudioso Iñaki Bazán Díaz cuando dice que las consideraciones sobre magia y hechicería son principalmente de índole histórica, que documentan estudios de casos e interpretan manuales referidos en lo esencial a la llamada 'Edad de Oro' de la brujería, ${ }^{3}$ que se corresponde con los siglos XVI y XVII de la Europa Moderna ${ }^{4}$ «dejando de lado, cuando no ignorando, la Edad Media, a la que sólo se recurre cuando se buscan noticias de épocas precedentes que anticipen esa Edad de Oro, sin tener en cuenta si existen diferencias entre la brujería medieval y la que se desarrollará a lo largo de la modernidad». ${ }^{5}$

Una segunda razón contemporánea que debería otorgarle cierta importancia a la visión de Tomás de Aquino sobre el arte de la magia, se cir-

2. Es muy común destacar el papel preponderante que tuvo para la Iglesia la doctrina de Tomás de Aquino en los siglos posteriores medievales y renacentistas. Sin embargo ello no supone un desarrollo doctrinal y profundo de su posición, sino, ante todo, el recuerdo de la condena de la magia como práctica demoníaca. Suele en ocasiones añadirse que la hermenéutica tomística está de acuerdo en lo esencial con aquella llevada a cabo por Agustín de Hipona según los tratados De Civiate Dei, De Trinitate y De divinatione Daemonum. No tiene objeto aquí trae a colación una desmedida enumeración de libros y artículos sobre magia y superstición, cuya mayoría enuncian antecedentes medievales y avanzan decididamente sobre la modernidad, los que, por lo demás, son fundamentalmente históricos. Baste, por ejemplo, consultar el clásico texto de F. CARDini (Magia, Brujería y Superstición en el Occidente medieval, Península, Barcelona, 1999) para dar con una valiosísma bibliografía o también, más recientemente, puede citarse a R. M. MÉRIDA JiMÉnez (Fuera de la orden de natura: magias, milagros y maravillas en el Amdís de Gaula, Ed. Reichenberger, Berlin, 2001). De todo lo cual no parece existir al día de hoy una visión de conjunto y acabada sobre la noción de magia en este doctor medieval, sino algunos fragmentos sobre algunas de sus especies, tales como la adivinación en general, la superstición o, en menor medida, sobre los maleficia.

3. Cfr. S. GIRALt, "Magia y ciencia en la Baja Edad Media: la construcción de los límites entre la magia natural y la nigromancia, c. 1230 - c. 1310", Clio y Crimen, n. 8, (2011), p. 18: "Ni la nigromancia ni la hechicería deben confundirse con lo que en la historiografía medieval y moderna recibe el nombre de brujería. Ésta bien poco tiene que ver con las prácticas mágicas documentadas históricamente sino con una imagen que se desarrolla a partir del siglo XIV en la mente de los teólogos y creyentes como antítesis del cristianismo y que, por consiguiente, se podría calificar más bien de 'antirreligión'."

4. I. BAZÁN DíAz, "El mundo de las supersticiones y el paso de la hechicería a la brujomanía en Euskal-Herria (Siglos XIII al XVI)", Vasconia, n. 25, (1998), p. 104. Nota al pie 1.

5. I. BAZÁn Díaz, "El mundo de las supersticiones...”, p. 104. Cfr. S. GiRAlt, "Magia y ciencia en la Baja Edad Media: la construcción...", p. 16: "Cuando los nuevos saberes naturales y las artes ocultas se extienderon por la Europa occidental los intelectuales vinculados a las universidades se enfrentaron a la necesidad de filtrarlos, integrándolos en la alta cultura cuando fueran lícitos o, en caso contrario, rebatiéndolos contundentemente por medio de la fe y la razón. Así, es sobre todo durante el siglo XIII cuando teólogos y filósofos naturales -especialmente vinculados a la Universidad de París, como Guillermo de Auvernia, Alberto Magno o Tomás de Aquino-, empiezan a distinguir entre dos tipos de magia de tradición escrita: una, a veces llamada magia natural, es compatible con la religión y las ciencias, mientras que la otra, normalmente denominada nigromancia -y en la actualidad magia ritual, ceremonial o

Thémata. Revista de Filosofía $\mathrm{N}^{\circ} 54$ (2016) pp.: 149-174. 
cunscribe al ámbito de la epistemología. En la crítica realizada por Feyerabend en su obra ¿Por qué no Platón? a los cánones cientificistas de la ciencia del s. XX se justriprecian y ponderan otro modos positivos de conocimiento del mundo, entre los cuales se menciona explícitamente el texto Malleus Maleficarum. ${ }^{6}$ Este filósofo de la ciencia si bien no encuentra lugar entre las discusiones acádemicas de la epistemología tomista, ${ }^{7}$ fue quizá el principal responsable de la corrosión de la estructura logicista y empirista de la ciencia, cuestión que sí importa también a la epistemología de raíz tomista.

De aquí se deduce, según se ha intentado mostrar, lo siguiente: existe (1) una velada presencia de la doctrina de Tomás de Aquino sobre magia en la epistemología contemporánea, ${ }^{8}(2)$ un desentendimiento de la epistemología tomista en lo relativo a la magia y (3) un amplio desconocimiento de la disciplina de la historia con respecto a la exacta opinión que tiene el Aquinate ${ }^{9}$ sobre la ciencia de la magia según textos sobre magia, hechicería y demonología medieval y moderna.

En conformidad con ello, se presentará una reconstrucción sistemática de Aquino sobre este arte y ciencia de la magia - en virtud de que no ela-

destinativa-, es contraria a ellas, pues va dirigida al dominio de los espíritus -que los escolásticos consideran siempre demonios- con el objetivo de servirse de su poder." Este texto en particular si bien trata de la magia en Tomás de Aquino, no la aborda en su completa extensión. Separa la magia natural (las operaciones ocultas de la naturaleza que están en la esfera de la cientificidad) de la magia promovida por los demonios. Empero, se identifica aquí esta acepción de magia con nigromancia (p. 16) lo cual no es del todo correcto, pues el Aquinate menciona otras tantas formas de prácticas mágicas.

6. P. K. Feyerabend, ¿Por qué no Platón?, Técnos, Madrid, 1982, pp. 83-84: "En 1484, la Iglesia católica romana publicó el Hexenhammer (martillo de brujas), magnífico manual sobre brujas [...] ¡Pero qué diferencia en erudición y cientificidad!: si el lector comparara el Hexenhammer con compendios del conocimiento actual, podría comprobar sin esfuerzos que el papa y sus doctos autores sabían de qué hablaban, cosa que no puede afirmarse de nuestros científicos [...]."

7. Los estudios sobre epistemología tomista no considerarían relevante ocuparse de la comprensión de Tomás sobre el arte y la ciencia de la magia. Su razón estaría fijada en una problemática enteramente diferente, en la que aún se discute la presunta fidelidad del Cardenal Tomás de Vío Cayetano a Tomás de Aquino, y específicamente, en lo relativo a la distinción de las ciencias especulativas por medio de la noción de abstracción. Cfr. J. M. F. MendozA, "Breve status quaestionis de la ciencia neotomista como introducción confusa al sentido de scientia tomística: algunas apreciaciones históricas en filósofos del siglo XX", Pensamiento, vol. 71, n. 267, 2015, pp. 617-630.

8. Cfr. P. K. Feyerabend, "La ética como medida de la verdad científica", en Provocaciones filosóficas, Biblioteca Nueva, Madrid, 2003, p. 80: "Teólogos como Santo Tomás y filósofos como Descartes o Leibniz interpretaron las leyes naturales como la obra de un ser divino estable y fidedigno, de un racionalista serio. Los enunciados que expresaban tales leyes eran, por lo tanto, objetivos y necesariamente verdaderos. Duns Scoto y Guillermo de Ockham, críticos ambos de Santo Tomás, enfatizaron el inmenso poder y la inescrutable voluntad de Dios que se manifiestan en los eventos particulares."

9. El siguiente estudio trae a colación y se estructura sobre la totalidad de pasajes en los que

Thémata. Revista de Filosofía Nº54 (2016) pp.: 149-174. 
boró un tratado específico sobre la mentada práctica demoníaca- con especial acento en su visión de las ciencias, lo cual parecería ser su locus propio.

\section{La beatitud como fin contemplativo en todas las ciencias in via}

Sólo en dos ocasiones Tomás de Aquino menciona que el estudio de la filosofía, y cualesquiera que sean sus divisiones, tiene siempre por fin la beatitudo. Término éste que en la tradición medieval significa «felicidad suprema constituida por la unión con Dios» ${ }^{10}$ y que fray Tomás parecería precisar en dos momentos: como aquella beatitudo in via e in patria, pues no es idéntica la fruición contemplativa en estado de viador que in coelo, la que se correspondería con el lumen gloriae. ${ }^{11}$ En el texto De Trinitate enuncia: "aún cuando en esto se divida la totalidad de la filosofía y de las artes, la división de la filosofía ${ }^{12}$ se hace respecto del fin [último que es] la

explícitamente Tomás de Aquino menciona las variantes declinativas del término magus (sustantivo y adjetivo). Conviene también señalar que todas las traducciones al español son personales. En virtud de ello también se mencionan, para una mejor comprensión de esta temática, algunos pasajes relevantes de la demonología en sí misma según el Aquinate. En este sentido considero importante completar un supuesto y despejar otro. Respecto de lo primero, facilitar una mirada completa y holística de este arte diabólico, en tanto las citas de Tomás suelen estar insertas en contextos donde se estudia la magia comparativamente con otros autores, lo cual impide o dificulta un desarrollo completo del tema. Finalmente respecto de lo segundo, suele mencionarse como texto clásico la breve obra De operationibus occultis naturae ad quendam militem ultramontanum para distinguir una vartiante de la magia 'buena' y otra 'mala'. No puede haber aquí mayor equívoco. No existe ningún pasaje en toda la obra de Tomás que habilite a pensar la posibilidad de una magia buena.

10. S. Magnavacca, Léxico técnico de filosofía medieval, Miño y Dávila, Buenos Aires, 1995, p. 109.

11. Parece que la expresión contemplatio no puede explorarse sin comprender el término beatitudo. En torno a la distinción señalada, puede verse, por ejemplo, H. PASQUA, "La vision béatifique selon saint Thomas d'Aquin et Dietrich de Freiberg", R.T., n. CXII, (2012), pp. 513527. Texto que da cuenta de la distinción entre ambos dominicos de beatitudo y lumen gloriae en relación con el intelecto en sus sentidos de agente y paciente. Cfr. B. Olivares Bøgeskov, "Sabiduría, felicidad y perfección: relación entre el conocimiento teórico y la bondad moral del fin último y la felicidad en el pensamiento de santo Tomás", Espíritu, LXII, n. 145, (2013), pp. 73-93. Artículo que destaca: 1. La contemplación suprema para el hombre, que es Sumo Bien, es su perfecta felicidad (p. 82); 2. Que esa felicidad es ascendente y es rectitud (pp. 83-84); 3. Que esa contemplación es "verdad afectiva" (p. 86).

12. Es sabido que hasta el s. XII la división de la filosofía es idéntica en esencia a la división de las siete artes liberales. Es también conocido que una sola vez Tomás trata -y lo hace velozmente- esta cuestión en el texto De Trinitate (II, q. 5, art. 1, arg. 3). Para una posible explicación sumaria de la asunción crítica de las artes liberales y su nueva organización en el mapa de ciencias elaborado por el de Aquino sobre su interpretación de los tratados aristotélicos, cfr. J. M. F. Mendoza, "Artes liberales y serviles en Tomás de Aquino: doctrina y división de las mismas (parte I)", Analogía Filosófica, vol. XXVIII, n. 2, (2014), pp. 3-23.

Thémata. Revista de Filosofía $\mathrm{N}^{\circ} 54$ (2016) pp.: 149-174. 
beatitudo, al cual toda la vida humana se ordena». ${ }^{13}$ Años después sostiene la misma tesis cuando, al comentar la letra de la Metafísica aristotélica, escribe: «todas las ciencias y todas las artes se ordenan a una, a saber, a la perfección del hombre que es su beatitudo». ${ }^{14}$

De la lectura de tales definiciones se evidencia que las expresiones 'filosofía' y 'ciencia' son intercambiables y que existe un camino de perfección natural para la persona allí donde la beatitud se concretiza en cada ciencia y cada arte. En primer lugar debe notarse que el fin de la totalidad de las ciencias, o lo que es lo mismo, la división de la filosofía, es la beatitu$d o$. Seguidamente, que ese fin es relativo a la experiencia de la persona en el estudio de las ciencias. Es por así decir, un fin personal siempre presente en todo el orden de saberes, lo que significa que tiene lugar como finalidad humana en la física, la gramática, la metafísica, la ética o cualquier otro saber científico sin detrimento del fin que se constituye como subiectum de cada ciencia por medio del cual ellas se diferencian. ${ }^{15}$

La presentación de esta finalidad última en el orden de ciencias destaca la valía de la vivencia personal en el estudio de las mismas en conjunto con las artes. No hay en Tomás de Aquino, según esta finalidad, un estudio meramente teórico de las ciencias como desentendido de la praxis, sino, por el contrario, una insistencia concreta en la experiencia de la comprensión de un determinado saber que conlleva en sí mismo y según el lugar de tal ciencia la experiencia de una felicidad de beatitud. Luego, si bien es sabido que el teólogo medieval del siglo XIII plasma entre sus escritos un completo orden quoad nos de ciencias, parecería con todo el haberse descuidado que ese orden atañe a cómo el hombre se modela internamente en su ascenso hacia la metafísica, y que está regido por un fin que atrae desde sí a toda persona en la contemplación amorosa, lo que, de suyo, recibe el nombre de fruición o contemplación afectiva. Por lo tanto, ahora aparece con mayor claridad que en cada ciencia se experiencia una determinada beatitud por cuanto sobre el orden de ciencias quod nos se

13. Tomás de Aquino, Sup. De Trin., II, q. 5, a. 1, ad 4: "Hoc tamen interest, cum in hec dividitur philosophia totalis et artes, quod in divisione philosophie habetur respectus ad finem beatitudinis, ad quem tota humana vita ordinatur."

14. Tomás de Aquino, Sent. Met., pr. 1: "Omnes autem scientiae et artes ordinantur in unum, scilicet ad hominis perfectionem, quae est eius beatitudo."

15. En Tomás de Aquino la distinción entre las cincias está dada por la definción de cada saber científico, la cual se arraiga en y se despliega de un determinado subiectum. Así, por ejemlplo, la filosofía de la naturaleza o ciencia física tiene por subiectum el ente móvil; la aritmética, el número abstracto o absoluto; o la metafísica, al ente en cuanto ente. Para una visión general del orden y la división de las ciencias en este dominico, cfr. J. M. F. MendozA, "Cartografía epistémica concebida por Tomás de Aquino según su interpretación de las obras aristotélicas”, Tópicos, n. 39, (2010), pp. 131-155.

Thémata. Revista de Filosofía №54 (2016) pp.: 149-174. 
pliega esta fruición contemplativa, cuya intensidad es relativa al lugar de cada saber científico.

De allí que una vez comprendido que la beatitud acompaña como fin personal a las ciencias, se entiende también que en la metafísica se halle mayor felicidad contemplativa que en los restantes saberes, pues si la metafísica es el nombre de la ciencia quoad nos de la teología, ${ }^{16}$ se revela que en esta ciencia su subiectum es el ente universal en tanto Dios, causa trascendente de todas las sustancias.

Ambos textos, antes de pronunciarse sobre la división de las ciencias, ponderan un recorrido y fin último que manifiesta un deseo interior, cuya concreción efectiva debe encontrarse gradualmente en el orden mentado. La beatitud, entendida de este modo, es la vivencia de felicidad trascendente -felicidad no efímera y terrena, sino permanente y eternaque plenifica al hombre entendido en ciencias. De allí también que esta finalidad, como felicidad constante que indica la dirección ascendente en el orden quoad nos científico - de la física a la teología-, ${ }^{17}$ sea entendida esencialmente no tanto como 'un programa de estudios' ${ }^{18}$ cuanto como un 'itinerario interior y pedagógico del espíritu humano', cuya dicha y goce aumenta al par de la creciente comprensión existencial de la naturaleza creada hasta contemplar a Dios in via, causa de todo ser y Esse per se subsistens.

De acuerdo con ello parecería que la beatitudo es la fruición personal resultante de la contemplación ${ }^{19}$ de los distintos estratos de la natura-

16. Tomás de Aquino, Sent. Met., pr.: "Dicitur enim scientia divina sive theologia, inquantum praedictas substantias considerat [Dios y los intelectos separados]. Metaphysica, inquantum considerat ens et ea quae consequuntur ipsum. Haec enim transphysica inveniuntur in via resolutionis, sicut magis communia post minus communia. Dicitur autem prima philosophia, inquantum primas rerum causas considerat. Sic igitur patet quid sit subiectum huius scientiae, et qualiter se habeat ad alias scientias, et quo nomine nominetur."

17. Tomás de Aquino, Sup. De Trin., II, q. 5, a. 1, ad 9: "[...] dicendum, quod quamvis scientia divina sit prima omnium scientiarum naturaliter, tamen quoad nos alie scientie sunt priores: ut enim dicit Avicenna in principio sue Metaphysice, ordo huius scientie est, ut addiscatur post scientias naturales [...] similiter etiam post mathematicas: indiget enim hec scientia ad cognitionem substantiarum separatarum cognoscere numerum et ordinem orbium celestium quod non est possibile sine astrologia, ad quam tota mathematica preexigitur."

18. Cfr. J.-B. Equivard, Une introduction à la philosophie. Les proèmes des lectures de saint Thomas d'Aquin aux oevres principales d'Aristote, L'esprit des disciplines fondamentales (1), F.-X. de Guibert, Paris, 2004, pp. 15-43: Podría decirse que esta visión del orden de las ciencias como un programa de estudios o introducción a la filosofía es razón insuficiente e incompleta, porque, si bien es sostenida por este autor en su prólogo comparándola con otros autores de la modernidad, no debe olvidarse la particular tensión teleológica tomísitica (beatitud) que aúna dicha división de los saberes y que podría plasmarse como programa de estudios sobre ciencias y artes.

19. Cfr. E. Martínez, "Bonum amatur inquantum es communicabile amanti. Amor y bien en

Thémata. Revista de Filosofía Nº54 (2016) pp.: 149-174. 
leza ${ }^{20}$ y principalmente de Dios. Ambas, contemplación y beatitud, se dan juntas en cada ciencia y en todo su orden jerárquico, pues Tomás dice en su comentario al Evangelio según san Juan:

Pero debe notarse que de diversa manera las distintas ciencias se dividen en estos tres modos de contemplación. En lo que respecta a la perfección de la contemplación que tiene la ciencia moral, que es sobre su fin último. En lo que concierne a la ciencia natural, que considera las cosas que proceden de Dios, [y también] a la grandeza de la contemplación entre las ciencias físicas que está en la metafísica. Pero el evangelio de [san] Juan, que contiene la división de las ciencias anteriormente mencionadas, lo contiene todo simultáneamente, y en virtud de ello es perfectísimo. ${ }^{21}$

\section{Las definiciones de filosofía y ciencia en Tomás de Aquino}

Una vez mostrada la primacía de la beatitudo como fruición contemplativa, fin último de todas las ciencias -especulativas, prácticas, lógicas y artes-, Tomás propone y desarrolla su propia comprensión de la división de las ciencias. No anula otras divisiones o relaciones de los distintos saberes mientras conduzcan al hombre a aquel bien concreto de la experiencia de la beatitudo. Su orden de ciencias se manifiesta como un todo flexible que emerge de su comprensión general de la filosofía y/o de la ciencia.

Para ello debe recordarse que la definición de filosofía esgrimida por el de Aquino «la filosofía determina las cosas existentes y [lo hace]

la metafísica de santo Tomás de Aquino", Espíritu, LXI, n. 143, (2012), pp. 73-93. Texto que me permito resumir en cuatro pasos según los intereses del presente artículo: 1. "La contemplación incluye la vertiente amorosa del bien, [y] que es difusivo de sí y que el dinamismo perfectivo de la vida personal culmina en la contemplación del Sumo Bien" (p. 74); 2. Que el bien pertenece a la potencia cognoscitiva en cuanto también en el intelecto hay felicidad ( $p$. 76); 3. Que en la contemplación amorosa del Bien perfecto, el ser humano sacia su anhelo de felicidad (p. 83).

20. Tomás De Aquino, De ver., q. 10 a. 1 ad 5: "[...] quod vivere addit supra esse, et intelligere supra vivere. Ad hoc autem quod in aliquo imago Dei inveniatur, oportet quod ad ultimum genus perfectionis perveniat quo creatura tendere potest; unde si habeat esse tantum, sicut lapides, vel esse et vivere, sicut plantae et bruta, non salvatur in hoc ratio imaginis; sed oportet ad perfectam imaginis rationem, ut creatura sit, vivat et intelligat."

21. TomÁs de Aquino, Sup. Io., pr. n. 1: "Sed notandum quod diversimode diversae scientiae istos tres modos contemplationis sortiuntur. Perfectionem namque contemplationis habet scientia moralis, quae est de ultimo fine; plenitudinem autem scientia naturalis, quae res a Deo procedentes considerat; altitudinem vero contemplationis inter scientias physicas habet metaphysica. Sed Evangelium Ioannis, quod divisim scientiae praedictae habent, totum simul continet, et ideo est perfectissimum."

Thémata. Revista de Filosofía №54 (2016) pp.: 149-174. 
según las razones tomadas desde las creaturas» $»^{22}$ es lo suficientemente general como para identificarse con cada ciencia en concreto. Esta definición figurada en su comentario de las Sentencias preanunciaba la de ciencia, en nada opuesta a la anterior, sino más precisa y terminante. De allí que la definición de ciencia, traída a colación sólo dos veces por Tomás, es aquella de inspiración aristotélica que dice: «decimos conocer cada cosa cuando conocemos las causas primeras y los primeros principios hasta [sus] elementos, esto es, hasta las causas próximas, como glosa el Comentador». ${ }^{23}$ La misma es nuevamente considerada en su comentario al tratado De Coelo cuando enuncia: "como dice el Filósofo en el [libro] I de la Física, que creemos conocer cada cosa cuando conocemos las causas primeras, y los primeros principios y hasta sus elementos». ${ }^{24}$

Tales tres definiciones muestran una única dirección: la consideraión de la naturaleza. La que es física, según sus diferentes estratos abióticos y biológicos - cuya mayor perfección es el hombre $-2^{25}$ y la que es meta-

22. Tomás De Aquino, Sup. Sent., q. 1, a. 1, ad 1: "quod, quamvis philosophia determinet de existentibus et secundum rationes a creaturis sumptas."

23. Tomás de Aquino, Q. D. De Ver. 2, a. 4, co., 143 - 147: "tunc cognoscere dicimur unumquodque cum causas cognoscimus primas et principia prima usque ad elementa, id est usque ad causas proximas, ut Commentator exponit."

24. Tomás de Aquino, In Coe., 1, pr. 1., pág. 1: "Sicut Philosophus dicit in I Physic., tunc opinamur cognoscere unumquodque, cum causas cognoscimus primas, et principia prima, et usque ad elementa."

25. Tomás de Aquino, In Gen., pr. n. 1: "Et ideo post considerationem motuum et mobilium in communi, quae fuit tradita in libro Physicorum, primo oportuit quod tractaretur de corporibus secundum quod moventur motu locali, in libro de Caelo; quae est secunda pars scientiae naturalis. Restat igitur consideratio de motibus aliis consequentibus, qui non sunt communes omnibus corporibus, sed inveniuntur in solis inferioribus. Inter quos principatum obtinet generatio et corruptio." Cfr. Tomás de Aquino, In Phys., lib. 1, 1. 1, n. 4: "et ideo statim in principio libri de caelo, qui sequitur ad istum, incipitur a notificatione corporis. Sequuntur autem ad hunc librum alii libri scientiae naturalis, in quibus tractatur de speciebus mobilium: puta in libro de caelo de mobili secundum motum localem, qui est prima species motus; in libro autem de generatione, de motu ad formam et primis mobilibus, scilicet elementis, quantum ad transmutationes eorum in communi; quantum vero ad speciales eorum transmutationes, in libro Meteororum; de mobilibus vero mixtis inanimatis, in libro de mineralibus; de animatis vero, in libro de anima et consequentibus ad ipsum." Cfr. Tomás de Aquino, De sensu, tr. 1, pr.: "Oportet ergo huiusmodi considerationem mediam in tres partes distingui. Quarum unum contineat ea que pertinent ad vivum inquantum est vivum; et hec continetur in libro quem scribit De morte et vita, in quo etiam determinat De respiratione et expiratione, per que in quibusdam vita conservatur, et De iuventute et senectute, per que diversificatur status vite; similiter autem et in libro qui inscribitur De causis longitudinis et brevitatis vite et in libro quem fecit De sanitate et egritudine, que etiam pertinent ad dispositionem vite, et in libro quem etiam dicitur fecisse De nutrimento et nutribili; qui duo libri apud nos nondum habentur. Alia vero pertineat ad motivum; que quidem continetur in duobus libris, scilicet in libro De causa motus animalium et in libro De progressu animalium, in quo determinatur de partibus animalium opportunis ad motum. Tercia vero pertinet ad sensitivum; circa quod

Thémata. Revista de Filosofía $\mathrm{N}^{\circ} 54$ (2016) pp.: 149-174. 
física, según trata sobre Dios y las sustancias intelectuales. ${ }^{26}$ La definición de filosofía comienza afirmando esta dirección con claridad al decir 'determina', lo que de suyo significa en las otras dos definiciones lo siguiente: 'las causas primeras, y los primeros principios y hasta sus elementos'. Luego el comentario a las Sentencias añade la expresión 'las cosas existentes', lo que no es sino la afirmación de la anunciada dirección a la naturaleza que en los otros tratados se precisa con los términos 'cada cosa'. Finalmente, la última parte de la mentada definición dice 'según las razones tomadas desde las creaturas', ${ }^{27}$ lo que confirma la dirección hacia la naturaleza según su constitución sustancial que, según las otras definiciones, señala el esclarecimiento de que esas razones son y se dicen 'sus causas, principios primeros y elementos o causas próximas'.

No pasa inadvertido que las tres definiciones señalan el orden previo de las ciencias mencionado como quoad nos. En efecto, la expresión 'cada cosa' equivale a 'cada sustancia', pero de modo especial a aquellas sustancias del universo creado material, porque el conocimiento del hombre, en quien se da la ciencia, comienza radicalmente por los sentidos. ${ }^{28}$ Luego, la ciencia primera, tanto para las definiciones de ciencia como para la de filosofía, es la física o filosofía natural. En cambio la ciencia última quoad nos será la metafísica o filosofía primera, porque ella versa sobre los primeros principios que también son sustancias, y en virtud de ello son cierta causa relativa a las sustancias materiales. Sustancias que en el ám-

considerari potest, et id quod pertinet ad actum interioris vel exterioris sensus, et quantum ad hoc consideratio sensitivi continetur in hoc libro, qui inscribitur De sensu et sensato, idest De sensitivo et sensibili, sub quo etiam continetur tractatus De memoria et reminiscencia. Et iterum ad considerationem sensitivi pertinet id, quod facit differenciam circa sensum in senciendo vel non senciendo, quod fit per sompnum et vigiliam de quo determinatur in libro qui inscribitur De sompno et vigilia."

26. Tomás de Aquino, Sup. De Trin., II, q. 5, a. 1, co.: "Quedam vero speculabilia sunt que non dependent a materia secundum esse, quia sine materia esse possunt, sive numquam sint in materia, sicut Deus et angelus, sive in quibusdam sint in materia et in quibusdam non, ut substantia, qualitas, ens, potentia, actus, unum et multa et huiusmodi; de quibus omnibus est theologia, id est scientia divina, quia precipuum in ea cognitorum est Deus. Que alio nomine dicitur metaphisica, id est trans phisicam, quia post phisicam discenda occurrit nobis, quibus ex sensibilibus oportet in insensibilia devenire; dicitur etiam philosophia prima, in quantum alie omnes scientie ab ea sua principia accipientes, eam consequntur."

27. Cfr. Tomás de Aquino, Sup. De Trin., pr.: "philosophi enim, qui naturalis cognitionis ordinem sequntur, preordinant scientiam de creaturis scientie divine, scilicet naturalem metaphisice, set apud theologos proceditur e converso, ut creatoris consideratio considerationem preveniat creature."

28. Tomás De Aquino, Sup. De Trin., II, q. 5, a. 1, ad 9: "Et praeterea, effectus sensibiles, ex quibus procedunt demonstrationes naturales, sunt notiores quoad nos in principio, set cum per eos pervenerimus ad cognitionem causarum primarum, ex eis apparebit nobis propter quid illorum effectuum ex quibus probabantur demonstratione quia; et sic et scientia naturalis aliquid tradit scientie divine, et tamen per eam sua principia notificantur."

Thémata. Revista de Filosofía No54 (2016) pp.: 149-174. 
bito de la filosofía primera reciben el nombre de 'divinas' y que propiamante se refieren a Dios y a los intelectos separados (ángeles bienaventurados y ángeles caídos) ${ }^{29}$ De esta manera también aquellas definiciones señalan la metafísica, no tanto en sí misma, sino más bien en dirección a, porque la búsqueda de la metafísica desde la física culmina en la aparición de la filosofía primera, ${ }^{30}$ que es el primer nombre quoad nos otorgado por Tomás a la metafísica.

A partir de lo dicho puede precisarse el fin particular de cada uno de estos saberes. El conocimiento filosófico, nos dice este fraile dominico, se divide en especulativo y práctico, mientras que las artes comportan una distinción similar. De este modo se pone de manifiesto aquí la existencia de un orden de fines. El primero de ellos, al cual todo le queda sujeto, es el fin último de la beatitudo. Le continúa la subordinación del fin de las ciencias especulativas, el fin de las ciencias prácticas y el fin de las artes. Y por último, en analogía con esta subordinación, el Aquinate menciona las ciencias y las artes concretas que están ordenadas a las ciencias especulativas, a las ciencias prácticas y a las artes.

\section{De la investigación científica a la práctica de la magia}

El comentario a las Sentencias pone de manifiesto el reverso de la actividad científica (cuyo fin último es la beatitud y cuyo sentido cabal, ahora puede precisarse, es la presencia de Dios en cada ciencia como re-

29. Tomás de Aquino, C. G., lib. 3, cap. 25, n. 9: "ipsaque prima philosophia tota ordinatur ad Dei cognitionem sicut ad ultimum finem, unde et scientia divina nominatur. Est ergo cognitio divina finis ultimus omnis humanae cognitionis et operationis." Cfr. Tomás DE Aquino, Sup. De Trin., II, q. 5, a. 1, co.: "de quibus omnibus est theologia, id est scientia divina, quia precipuum in ea cognitorum est Deus, que alio nomine dicitur metaphisica, id est trans phisicam, quia post phisicam discenda occurrit nobis, quibus ex sensibilibus oportet in insensibilia devenire; dicitur etiam philosophia prima, in quantum alie omnes scientie ab ea sua principia accipientes, eam consequntur."

30. TomÁs de Aquino, Sent. Met., lib. 7, 1. 11: "Haec enim perscrutatio est propria huic scientiae. In hac enim scientia tentamus determinare de substantiis sensibilibus huius gratia, idest propter substantias immateriales, quia speculatio circa substantias sensibiles et materiales quodammodo pertinet ad physicam, quae non est prima philosophia, sed secunda, sicut in quarto habitum est. Prima enim philosophia est de primis substantiis quae sunt substantiae immateriales, de quibus speculatur non solum inquantum sunt substantiae, sed inquantum substantiae tales, inquantum scilicet immateriales." Cfr. Tomás DE Aquino, Sent. Met., lib. 6, 1. 1: "si non est aliqua alia substantia praeter eas quae consistunt secundum naturam, de quibus est physica, physica erit prima scientia. Sed, si est aliqua substantia immobilis, ista erit prior substantia naturali; et per consequens philosophia considerans huiusmodi substantiam, erit philosophia prima."

Thémata. Revista de Filosofía $\mathrm{N}^{\circ} 54$ (2016) pp.: 149-174. 
flejo de aquella que está en cada estrato de la naturaleza). En este sentido el texto dice:

[...] aquellas cosas relativas a la facultad humana y a la naturaleza, solamente a Dios deben ser solicitadas; y por ello así como peca gravemente quien atribuye con vehemencia aquello que es de Dios a las creaturas en razón del culto idolátrico, así gravemente pecan quienes desean aquello que es de Dios al implorar ayuda de los demonios. Y de estas cosas es el vaticinio de los eventos futuros; de donde se dice en Isaías 8, 19: ¿Acaso el pueblo no consultará lo que es de Dios? Y similarmente también en las otras actividades mágicas, en las que se espera el concurso de los demonios para completar las obras: y en cada una de ellas hay apostasía de fe por pacto emprendido con el demonio, o por medio de las palabras, si hay invocación; o por medio de un hecho, incluso si no hay sacrificios. En efecto, no puede el hombre servir a dos señores, como dice Mt $6,24 .^{31}$

El fragmento es muy claro. Si la ciencia, actividad humana contemplativa de la naturaleza, está dirigida desde el comienzo hacia Dios, la magia, por el contrario, exige de suyo la participación demoníaca. En efecto, todo acto de magia es principalmente, en virtud de este lazo entre los hombres y los demonios, un acto de apostasía de fe. No hay magia sin el concurso de los ángeles caídos, y toda actividad mágica emprendida por los hombres supone una previa perversión de su moral.

Es sabido que la ciencia moral del Aquinate está en cierto modo presente en todo acto de la inteligencia, porque ella quiere conocer. Mas, ese querer del intelecto puede corromperse y volverse curiositas -como vicio opuesto a la virtud de la studiositas ${ }^{32}$ y así pervertirse la ciencia y obnubilarse su fin. No se estudia por amor a la verdad ni se contempla a Dios en la naturaleza, como tampoco se investiga en pos de esta dirección. Por el contrario, los conocimientos adquiridos ahora están al servicio de una comprensión de lo oculto de la naturaleza, ${ }^{33}$ que símil a los milagros (por

31. Tomás de Aquino, Sup. Sent., lib. 2 d. 7 q. 3 a. 2 co.: "Respondeo dicendum, quod ea quae sunt supra facultatem humanam et naturae, a solo Deo requirenda sunt; et ideo sicut graviter peccat qui illud quod est Dei, creaturae impendit per idolatriae cultum; ita graviter peccant qui ea quae a Deo expetenda sunt, auxilio Daemonum implorant: et hujusmodi est vaticinatio de futuro; unde dicitur Isai. $(8,19)$ : numquid non populus a Deo suo requiret? Et similiter etiam in aliis operibus magicis; in quibus complementum operis ex virtute Daemonum expectatur: in his enim omnibus est apostasia a fide per pactum initum cum Daemone, vel verbotenus, si invocatio intersit, vel facto aliquo, etiam si sacrificia desint: non enim potest homo duobus dominis servire, ut dicitur Matth. (6, 24)."

32. Para un desarrollo propicio de ambas nociones, cfr. D. VÁzquez Ramos, La virtud de la studiositas y el conocimiento. Un estudio desde Tomás de Aquino, Eunsa, Pamplona, 2009.

33. Tomás de Aquino, C. Gen., lib. 3 cap. 105 n. 3: "Virtus faciendi non acquiritur per disciplinam, sed solum cognitio aliquid faciendi. Per disciplinam autem aliqui acquirunt quod huiusmodi operationes magicas efficiant."

Thémata. Revista de Filosofía No54 (2016) pp.: 149-174. 
pura y mera apariencia), ${ }^{34}$ incursionan en las artes mágicas. Ellos no dan cuenta de las verdaderas causas y principios de las sustancias, sino solo de aquello que le conviene a los demonios (que pueden ser verdaderas causas o no) ${ }^{35}$ para alimentar el vicio de la concupiscencia científica de los hombres, pues: «Agustín dice en el libro De Vera Religione que la concupiscencia de los ojos vuelve a los hombres curiosos. O también como dice Beda, que la concupiscencia de los ojos está no sólo en el aprendizaje de las artes mágicas, sino también en la contemplación de los espectáculos, [...]». ${ }^{36}$

Si el fin de la ciencia es la beatitudo, su corrupción es la curiositas, porque ella se comporta como el principio de decandencia e inmoralidad en

34. Tomás de Aquino, S. Th., I, q. 114 a. 4 s.c.: "Sed contra est quod Augustinus dicit, libro octoginta trium quaest. quod magicis artibus fiunt miracula plerumque similia illis miraculis quae fiunt per servos Dei." Cfr. Tomás de Aquino, Comp. Th., lib. 1 cap. 136 co.: "Alia vero omnia huic ordini subduntur, unde miracula facere, solius Dei est, secundum illud Psalmistae: qui facit mirabilia magna solus. Cum igitur ab aliqua creatura miracula fieri videntur, vel non sunt vera miracula, quia fiunt per aliquas virtutes naturalium rerum, licet nobis occultas, sicut est de miraculis Daemonum, quae magicis artibus fiunt; vel si sunt vera miracula, impetrantur per aliquem a Deo, ut scilicet talia operetur." Existen numerosos pasajes de índole bíblica que buscan distanciar exegéticamente los milagros de la magia. Cfr. Tomás DE Aquino, De Rat. Fidei, cap. 8 co.: "Ut igitur corpus Christi et sanguis spiritualis et divina refectio haberetur, et omnino quasi cibus et potus communis, non sub propria carnis et sanguinis nobis traduntur specie sed sub specie panis et vini; [...] Nec tamen hoc sic fieri dicimus quasi species illae quae sensibus apparent in sacramento altaris sint solum in phantasia videntium, sicut solet esse in praestigiis artium magicarum, quia veritatis sacramentum nulla fictio decet [...]." Cfr. Tomás De Aquino, Cat. in Mt., cap. 1 1. 13: "[...] Ut autem non contemnerentur neque fabulosa ducerentur quae apostoli nuntiabant, demonstrantur haec a prophetis fuisse praedicta, quia etsi attestabantur miracula, non defuissent qui magicae potentiae cuncta illi tribuerent, nisi talis eorum cogitatio contestatione prophetica vinceretur. Magicis enim artibus [...]." Cfr. Tomás de Aquino, Cat. in Mt., cap. 12 1. 9: "Primo ipsi Pagani, cum dicunt Christum magicis artibus fecisse miracula, nonne similes sunt his qui dixerunt eum in principe Daemoniorum eiecisse Daemonia? Iudaei etiam, et quicumque haeretici qui spiritum sanctum confitentur, sed negant eum esse in corpore Christi, quod est Ecclesia Catholica, similes sunt Pharisaeis, qui negabant spiritum sanctum esse in Christo." Cfr. Tomás de Aquino, Cat. in Lc., cap. 24 1. 5: "Augustinus de Cons. Evang. Illud attendant qui magicis artibus Christum tanta potuisse, et nomen suum ad apostolos in se convertendos arte ipsa consecrasse delirant, [...]." Cfr. Tomás de Aquino, Cat. in Lc., cap. 23 1. 3: "Pereant ergo scripta quae post tanto tempore contra Christum composita, non illum apud Pilatum magicae artis accusatum, sed componentes, apud dominum perfidiae et falsitatis accusandos esse demonstrant."

35. Esto puede suceder en razón de Dios. Cfr. Tomás DE Aquino, De malo, q. 16 a. 4 ad 23: "[...] quod Diabolus dicitur loqui mendacium ex propriis, non quia mendacium sit naturalis proprietas eius, sed quia ea quae sunt vera non habet a seipso, sed a Deo; quod autem falsa loquatur hoc habet a seipso, non autem a Deo." Cfr. Tomás De Aquino, De malo, q. 16 a. 5 ad 21: "[...] quod sicut Diabolus immobiliter perseverat in malo cui inhaeret, ita etiam immobiliter perseveraret in falso cui assentiret."

36. Tomás De Aquino, S. Th., II-II, q. 167 a. 2 s.c.: "Sed contra est quod Augustinus dicit, in libro de vera Relig. quod concupiscentia oculorum reddit homines curiosos. Ut autem dicit Beda, concupiscentia oculorum est non solum in discendis magicis artibus, sed etiam in con-

Thémata. Revista de Filosofía $\mathrm{N}^{\circ} 54$ (2016) pp.: 149-174. 
el ámbito de lo científico, pervirtiendo la disposición humana a la contemplación. Este modo de la concupiscencia propio de quien estudia ciencia inmoralmente, comienza por un menor esfuerzo por parte de la inteligencia en la investigación de la ciencia y culmina, en el caso de que continúe, en la práctica de las artes mágicas, afectando la entera comprensión humana de la naturaleza en razón de la influencia de los demonios, ${ }^{37}$ ya que, nos dice Tomás, "por parte de lo cognoscible hay tres accidentes. Uno, cuando lo cognoscible [promueve] la declinación de lo fácil a lo malo, y además en sí mismo es de poca utilidad; y por su causa están prohibidas las ciencias mágicas para que el hombre no se deje llevar en su ejercicio». ${ }^{38}$ Empero, si tales artes mágicas se estudian para ser reprobadas, no hay curiositas intelectual, pues: «si alguien desea saber ciencias mágicas y cómo también valerse de ellas es malo. Sin embargo, si alguien desea saber aquellas, y cómo son detenidas y reprobadas, así es bueno y lícito». ${ }^{39}$ Sólo bajo este aspecto «debe investigarse de dónde las arte mágicas toman [su] eficacia. Lo que sin duda fácilmente puede sopesarse -continúa diciendo el Aquinate- si se atiende al modo de sus acciones». ${ }^{40} \mathrm{Y}$ tales acciones, que son obra-

templandis spectaculis, et in dignoscendis et carpendis vitiis proximorum, quae sunt quaedam particularia sensibilia. Cum ergo concupiscentia oculorum sit quoddam vitium, sicut etiam superbia vitae et concupiscentia carnis, contra quae dividitur, I Ioan. II; videtur quod vitium curiositatis sit circa sensibilium cognitionem."

37. Los demonios influyen sugiriendo, no conociendo directamente la interioridad de la persona. Y el demonio puede sugerir (tentar) porque conoce por medio de los signos corporales más sutiles de las personas qué cosas le agradan. De este modo se dice que conocen nuestros pensamientos, no por sí mismos, sino por nuestras manifestanciones corporales. Cfr. Tomás DE Aquino, De malo, q. 16 a. 8 ad 13: “[...] quod Daemon melius cognoscit cogitationes quam anima alterius hominis, non quia videat eas in se, sed quia videt eas per exteriora signa magis occulta." Cfr. Tomás De Aquino, De malo, q. 16 a. 8 ad 14: "[...] quod idem signum corporale in generali potest respondere multis effectibus; sed tamen in speciali sunt aliquae differentiae, quas Daemon melius potest percipere quam homo." Cfr. Tomás DE Aquino, De malo, q. 16 a. 11 co.: "Et per hunc modum Daemones possunt immutare imaginationem et sensum, non solum dormientium, sed etiam vigilantium." Cfr. Tomás DE Aquino, De malo, q. 16 a. 12 ad s. c.: "[...] quod Daemon dicitur ingredi posse mentem hominis, non secundum substantiam, sed secundum effectum; in quantum scilicet instigat hominem ad aliquid cogitandum. Dicitur etiam, quod potest uti anima sapientis ut vult, in quantum aliquando, Deo permittente, impedit usum rationis in homine, sicut patet in arreptitiis."

38. Tomás de Aquino, Sup. Sent., lib. 3 d. 35 q. 2 a. 3 qc. 3 co.: "Ex parte vero cognoscibilis est triplex accidens. Unum est quando cognoscibile de facili ad malum inclinat, et praeterea in se parvae utilitatis est; et propter hoc prohibitae sunt scientiae magicae, ne homo in exercitium earum labatur."

39. TomÁs de Aquino, Quodlibet IV, q. 9 a. 1 co.: "Nam si aliquis appetat scire scientias magicas ut eis etiam utatur, est malum. Si autem appetat eas scire ut eas confutet et reprobet, sic est bonum et licitum."

40. Tomás de Aquino, C. Gen., lib. 3 cap. 105 n. 1: "Investigandum autem relinquitur unde artes magicae efficaciam habeant. Quod quidem facile perpendi potest si modus operationis earum attendatur." Sin embargo también es cierto que Tomás de Aquino aclara que la inves-

Thémata. Revista de Filosofía No54 (2016) pp.: 149-174. 
das por demonios a través de los hombres, se realizan mediante palabras o hechos ${ }^{41}$ eficaces:

Los signos no se utilizan sino para otros seres inteligentes. Por lo tanto, las artes mágicas tienen eficacia por otro ser inteligente a quien la palabra del mago está dirgida. ${ }^{42}$

\section{Y esta eficacia supone la permanencia de la acción de los demonios inferiores en determinadas sustancias inferiores.}

Que alguna sustancia espiritual sea obligada por algún cuerpo, no es por virtud de la potencia del cuerpo que retiene la sustancia incorpórea; pero por virtud de alguna sustancia superior que las seduce, la sustancia espiritual [permance] en tal cuerpo. Como [sucede] también por las artes mágicas, por permisión divina, que por fuerza de demonios superiores son seducidos algunos espíritus [para permancer] sobre algunas cosas, como sobre los anillos, las imágenes, o cosas de este modo. Y por medio de esta manera las almas y los demonios son seducidos, por virtud divina, para su pena en el fuego corpóreo. ${ }^{43}$

\section{Tomás llama 'ciencia' a la magia cuando tiene por fin conocer qué} sean los demonios ${ }^{44} \mathrm{y}$ cuáles sus acciones en orden a influir negativamente

tigación de la primera verdad, la cual compete a la ciencia metafísica, es preferible al estudio de las artimañas de los demonios. Cfr. Tomás DE Aquino, Quodlibet IV, q. 9 a. 1 ad 1: "quod omnis scientia ponit intellectum in aliquo sui bono, quia omne verum est quoddam bonum intellectus; sed non omnis scientia ponit intellectum in sui optimo, sed illa sola quae est circa primam veritatem. Nec etiam verum est quod magicae artes sint scientiae, sed potius sunt quaedam fallaciae Daemonum."

41. Tomás de Aquino, De pot., q. 6 pr. 10: "Decimo utrum Daemones cogantur aliquibus sensibilibus et corporalibus rebus, factis aut verbis ad miracula facienda, quae per magicas artes fieri videntur." Cfr. Tomás DE Aquino, De op. occultis naturae: "Hae igitur actiones quae per huiusmodi verba fiunt, vel per quascumque imagines vel sculpturas, vel quaecumque alia huiusmodi, non sunt naturales, utpote non procedentes a virtute intrinseca, sed sunt empericae; et ad superstitionem pertinentes."

42. Tomás de Aquino, C. Gen., lib. 3 cap. 105 n. 7: "Signis autem non utimur nisi ad alios intelligentes. Habent igitur magicae artes efficaciam ab alio intelligente, ad quem sermo magi dirigitur."

43. Tomás de Aquino, Q. d. De An., a. 21 co.: "Quod autem aliqua spiritualis substantia alicui corpori obligetur, non est ex virtute corporis potentis substantiam incorpoream detinere; sed ex virtute alicuius superioris substantiae alligantis spiritualem substantiam tali corpori. Sicut etiam per artes magicas, permissione divina, virtute superiorum Daemonum aliqui spiritus rebus aliquibus alligantur, vel anulis, vel imaginibus, vel huiusmodi rebus. Et per hunc modum animae et Daemones alligantur, virtute divina, in sui poenam, corporeo igni."

44. Es sabido que en el desarrollo de la demonología medieval numerosos teólogos opinaron que los demonios tenían un cuerpo sutil y que vagaban por el aire. Esta visión que parece originaria de San Agustín es recogida por Tomás sosteniendo a la vez cierta distancia. No la refuta, aunque no se inclina convincentemente, pues termina entendiendo que los ángeles

Thémata. Revista de Filosofía Nº54 (2016) pp.: 149-174. 
en las personas. Negatividad que puede traducirse en torcer su voluntad y oscurecer su inteligencia con la sutileza de la percepción que entiende de inclinaciones humanas. Y llama 'arte' a la magia cuando ya los mismos hombres, seducidos por los demonios, se valen de distintos artilugios que producen fascinación y deleite ${ }^{45}$ (porque se desconocen sus causas -aquellas que son constitutivas de las sustancias-, porque son prodigios realizables en la naturaleza y porque provocan en el alma sensación de poder sobre la naturaleza y sobre las personas).

Esta breve descripción permite entrever un descenso de influencias desde la metafísica hacia la física. En primer lugar se hallan los demonios como causa real y próxima de la magia, ${ }^{46}$ luego los magos, como causa real, próxima e instrumental (por la manipulación demoníaca) de la magia, y finalmente, la realización concreta y efectiva de la magia sobre diferentes personas u objetos.

Empero, Dios es causa en su preciso sentido de 'permiso' para que los demonios tienten y seduzcan, transformando, también y co-principal-

son intelectos separados, carentes de suyo de toda materia. Cfr. Tomás DE Aquino, De malo, q. 16 a. 1 co.: "[...] quod sive Daemones habeant corpora sibi naturaliter unita, sive non habeant, hoc non multum refert ad fidei Christianae doctrinam." Sin embargo, en relación con la corporalidad de los demonios se sostiene la sujeción del cuerpo al demonio y no la sujeción de los demonios a los cuerpos. Para ello, cfr. Tomás de Aquino, De malo, q. 16 a. 1 ad s. c. 1: "[...] posset responderi, si quis sustineret quod Daemones habent corpora aerea, quod Daemones non subduntur suis corporibus sicut nos, sed magis habent corpus suum sibi subiectum, ut Augustinus dicit super Genes. ad litteram. Unde magis possunt Daemones dici spiritus quam nos, quamvis habeant corpora naturaliter sibi unita; praesertim quia etiam ipse aer spiritus nominatur."

45. Tomás de Aquino, Sup. Gal., cap. 3 1. 1: "Et ideo istum gradum insensationis in eis reprehendit, dicens quis vos fascinavit, etc. Ad sciendum autem quid sit fascinatio, sciendum est, quod secundum Glossam fascinatio proprie dicitur ludificatio sensus, quae per artes magicas fieri consuevit; puta cum hominem facit aspectibus aliorum apparere leonem vel cornutum, et huiusmodi. Et hoc etiam per Daemones potest fieri, qui habent potestatem movendi phantasmata, et reducendi ad principia sensuum, ipsos sensus immutando."

46. Porque los demonios poseen un conocimiento perfecto inalterado de todo lo que le es inferior (lo que de suyo atañe a su naturaleza metafísica), y ello señala su conocimiento natural. Empero, pueden errar en lo tocante a un conocimiento que les sea superior, como el propio de los misterios de Dios. Cfr. Tomás de Aquino, De malo, q. 16 a. 6 ad s. c. 4: "[...] quod modus intelligendi ipsius Daemonis conformatur substantiae suae: non tamen oportet quod eamdem vim habeat ad iudicandum de his quae excedunt naturam suam, sicut ad iudicandum ea quae sunt sibi connaturalia. Et ideo licet nunquam falsum iudicium habeat de his quae pertinent ad naturalem cognitionem eius, potest tamen habere falsum iudicium de his quae naturalem eius cognitionem excedunt." Cfr. Tomás DE Aquino, De malo, q. 16 a. 6 ad s. c. 7: "[...] quod quia culpa non directe opponitur naturae, inde est quod Daemones, per peccatum non incurrerunt falsitatem quantum ad naturalem cognitionem."

Thémata. Revista de Filosofía №54 (2016) pp.: 149-174. 
mente por elección de las personas, a muchas de ellas en magos. El texto De Potentia dice:

Por ello, resta que los demonios, a través de los cuales las artes mágicas hallan complemento, se reúnan y seduzcan. Son reunidos, sin duda, por alguien superior; ya sea por el mismo Dios, ya sea por los santos, los ángeles y los hombres por virtud de Dios. ${ }^{47}$

Esta causalidad del ejercicio de la libertad, primero por permiso divino, luego por una cadena de seducciones que comienza en los demonios y termina en los hombres, vuelve en cierto sentido también a los demonios, quienes no dejan de deleitarse ${ }^{48}$ por las inmorales acciones humanas. En efecto, es sabido que los demonios son maestros de seducción en orden a la declinación del alma para la práctica del mal. ${ }^{49}$ Esta es la primera y superior co-causa. Su complemento, la co-causa inferior y segunda, aunque sin ella es imposible la práctica de la magia, es la libre aceptación, por previa seducción demoníaca, de la enseñanza de este arte malhechor. De aquí la importancia en el texto del término 'complemento' en cuanto referencia la co-causalidad humana-demoníaca en lo que hace a la efectividad de la magia. Sin embargo, dicho complemento, aclara Tomás, es, para el caso de los demonios, coactivo, pues «también se reúnen de vez en cuando por los

47. TomÁs De Aquino, De pot., q. 6 a. 10 co.: "Restat ergo quod Daemones, per quos magicae artes complementum habent, et coguntur et alliciuntur. Coguntur quidem a superiori; quandoque quidem ab ipso Deo, quandoque vero a sanctis et Angelis et hominibus virtute Dei."

48. Tomás de Aquino, De pot., q. 6 a. 10 co.: "Secundo, inquantum huiusmodi corporalia sunt signa aliquorum spiritualium quibus delectantur." Cfr. Tomás de Aquino, S. Th., II-II, q. 96 a. $2 \mathrm{ad} 2$ : "Et inde est quod ex impressione caelestium corporum nullam virtutem sortiuntur inquantum sunt artificialia, sed solum secundum materiam naturalem. Falsum est ergo quod Porphyrio videbatur, ut Augustinus dicit, X de Civ. Dei, herbis et lapidibus et animantibus, et sonis certis quibusdam ac vocibus, et figurationibus atque figmentis quibusdam etiam observatis in caeli conversione motibus siderum, fabricari in terra ab hominibus potestates idoneas siderum variis effectibus exequendis, quasi effectus magicarum artium ex virtute caelestium corporum provenirent. Sed sic ut Augustinus ibidem subdit, totum hoc ad Daemones pertinet, ludificatores animarum sibi subditarum." Cfr. Tomás de Aquino, De pot., q. 6 a. 10 co.: "Dicendum quod circa effectus magicarum artium multiplex fuit opinio. Quidam enim dixerunt, sicut Alexander, quod effectus magicarum artium fit per aliquas potentias et virtutes in rebus inferioribus generatas ex virtutibus quorumdam inferiorum corporum, cum observatione caelestium motuum. Unde Augustinus dicit, quod Porphyrio videtur, herbis et lapidibus et animantibus et sonis certis quibusdam ac vocibus et figurationibus atque figmentis quibusdam, etiam observatis in caeli conversione motibus sidereis, fabricari in terra ab hominibus potestates idoneas siderum variis effectibus exequendis."

49. Tomás de Aquino, Sup. Gal., cap. 5 1. 5: "Sap. XIV, 27: infandorum enim idolorum cultura omnis mali causa est et initium et finis. Aliud est per quod initur pactum cum Daemonibus; et quantum ad hoc dicit veneficia, quae fiunt per magicas artes, et dicuntur veneficia a veneno, quia fiunt in nocumentum hominum. I Cor. X, 20: nolo vos fieri socios Daemoniorum.”

Thémata. Revista de Filosofía №54 (2016) pp.: 149-174. 
mismos demonios superiores; lo que, sin duda, puede hacerse únicamente por coacción a través de las artes mágicas». ${ }^{50}$

En torno a la presencia de los demonios para la práctica de la magia se torna esclarecedora la siguiente cadena de razonamientos tomísticos:

\begin{abstract}
Pero consta que la palabra no es sino por el intelecto. Pero por medio de las artes mágicas se escuchan las palabras de quienes responden [es decir, de los demonios]. Y de allí también conviene que esto sea por cierto intelecto, lo que principalmente por la enseñanza de ciertas [artes] ocultas [se daría a conocer] la respuesta a los hombres. Pero tampoco puede decirse que esto se hace por la inmutación de la sola imaginación a través de la charlatanería: porque entonces estas voces no se oirian [por todos] en todas las circunstancias, por más vigilantes que estén también los sentidos liberados para que puedan oirse tales voces. De aquí que se haya dejado de lado que se realizan o por la fuerza del alma humana que utiliza las artes mágicas, o se realizan por alguien exterior que es inteligente. Pero lo primero no puede ser, lo que se evidencia por dos razones: en primer lugar, porque el alma humana por su propia fuerza no puede venir al conocimiento de lo que ignora sino por algo en sí evidente. De donde, por la [sola] voluntad del alma humana no puede hacerse una revelación de cosas ocultas realizada a través de las artes mágicas, ya que no bastan los principios de la razón para que se realicen hechos ocultos. Segundo, porque si por su virtud el alma produjera de algún modo un efecto de magia, no necesitaría utilizar invocaciones o algunas [otras] cosas exteriores. Sin embargo consta que ciertos efectos de las artes mágicas se realizan por algunos espíritus exteriores, y no por espíritus justos y buenos, lo que sin duda se evidencia por dos razones. Primero, porque los espíritus buenos no exhibirían su familiaridad a los hombres criminales, que [además] son a menudo ejecutores de las artes mágicas. Segundo, porque no cooperan con los hombres para perpetrar actos ilícitos, que a menudos se realizan por medio de las artes mágicas. Queda, por lo tanto, que esto se realice por espiritus malos, y que nosotros llamamos demonios. ${ }^{51}$
\end{abstract}

\title{
En consecuencia, no cabe duda sobre la participación de los demo- nios en la realización de las artes mágicas. Debe notarse que a los magos
}

50. Tomás de Aquino, De pot., q. 6 a. 10 co.: "Coguntur etiam interdum ab ipsis superioribus Daemonibus; quae quidem sola coactio per magicas artes fieri potest." Cfr. Tomás DE Aquino, De pot., q. 6 a. 10 ad 1: "Daemones dicuntur cogi per magicas artes modis praedictis."

51. Tomás de Aquino, De pot., q. 6 a. 10 co.: "Constat vero quod locutio non est nisi ab intellectu. Per magicas autem artes aliquae locutiones aliquorum respondentium audiuntur; unde et oportet quod hoc fiat per aliquem intellectum, et praecipue cum de aliquibus occultis per huiusmodi responsa homines doceantur. Nec potest dici, quod hoc fiat per immutationem imaginationis solius per modum praestigii: quia tunc istae voces non ab omnibus circumstantibus audirentur, nec a vigilantibus et habentibus sensus solutos istae voces audiri possent. Unde relinquitur quod fiant vel ex virtute animae hominis magicis artibus utentis, aut fiant ab aliquo exteriori intellectum habente. Primum autem esse non potest: quod patet ex duobus: primo quidem, quia anima hominis ex sua virtute non potest venire ad cognitionem ignotorum nisi per aliqua sibi nota; unde ex voluntate animae hominis non potest fieri revelatio occultorum quae fit per magicas artes, cum ad huiusmodi occulta facienda non sufficiant principia rationis. Secundo, quia si sua virtute huiusmodi effectus anima magi faceret, non indigeret uti invocationibus aut aliquibus huiusmodi exterioribus rebus. Constat autem quod huiusmodi effectus magicarum artium per aliquos exteriores spiritus fiunt, non autem per spiritus iustos et bonos: quod quidem ex duobus patet: primo, quia boni spiritus familiari-

Thémata. Revista de Filosofía N54 (2016) pp.: 149-174. 
también se los llama criminales (sceleratus) y que, según antes se anticipó, no realizan milagros y no estudian la naturaleza conforme a la predisposición interior humana de la búsqueda de beatitud. Ya no hay contemplación, sino fascinación por el dominio de los elementos de la naturaleza. En este sentido los magos no realizan 'milagros' sino 'prodigios de poder', ${ }^{52}$ ya que "[los demonios] también se reúnen, por así decir, para seducir por medio de las artes mágicas, no por las cosas corporales a causa de sí mismas, sino por un propósito superior» ${ }^{53}$ Esta aclaración permite desvincular la magia de los santos, de los justos de corazón y de los ángeles, porque ellos contemplan a Cristo, quien no realizó jamás magia alguna sino milagros. La Summa Theologiae orienta al respecto:

De allí que también respecto de la Sabiduría se diga en Prov. IX que "envió sus doncellas y clama a la ciudad" (Prov. IX, 3). Sin embargo también debe saberse, según enseña Agustín en el [libro] I de la Concordancia de los Evangelistas, que algunos gentiles estimaban que Cristo había escrito estos libros conteniendo artes mágicas, las cuales realizaban milagros, y que la disciplina cristiana condena. Y sin embargo aquellos que afirman haber leído tales libros de Cristo, no realizan ninguna de tales acciones que estos libros hicieron y que ellos admiran. ${ }^{54}$

tatem suam sceleratis hominibus non exhiberent, quales plerumque sunt magicarum artium executores; secundo, quia non cooperarentur hominibus ad illicita perpetranda, quod plerumque fit per magicas artes. Restat ergo hoc fieri per malos spiritus quos Daemones dicimus."

52. Cfr. Tomás De Aquino, De malo, q. 16 a. 9 ad 2: "Et similiter Daemones per activa naturalia, quae adhibent ad effectus, possunt quaedam facere ultra virtutem naturalium agentium: non tamen hoc quod humani corporis lineamenta in bestialia convertantur secundum rei veritatem, quia hoc est praeter ordinem a Deo naturae inditum." Cfr. Tomás de Aquino, De malo, q. 16 a. 9 ad 11: "[...] quod signa sive miracula quae magi faciunt per privatos contractus Daemonum, non sunt supra ordinem universalium causarum, sicut illa quae virtute divina fiunt, sed fiunt virtute activorum naturalium supra hominum comprehensionem et facultatem, propter tria: primo quidem, quia Daemones magis cognoscunt naturalium activorum virtutem quam homines; secundo, quia celerius possunt ea congregare; tertio, quia activa naturalia, quae assumunt ut instrumenta, se possunt extendere ad maiores effectus ex virtute vel arte Daemonum, quam ex virtute vel arte hominum; et sic hominibus miracula videntur quae per Daemones fiunt; sicut etiam hominibus inexpertis videntur miracula quae per aliquos artifices fiunt."

53. El texto completo muestra la admiración que provoca la magia, que a fin de separarla de aquella de los milagros, que se produce por los justos y santos, la he llamado "prodigios de poder $\square$. Cfr. Tomás de Aquino, De pot., q. 6 a. 10 co.: "Coguntur etiam quasi allecti per artes magicas, non quidem rebus corporalibus propter seipsas, sed propter aliquid aliud. primo quidem, quia per huiusmodi res corporales sciunt facilius posse compleri effectum ad quem invocantur; et hoc ipsi appetunt, ut scilicet eorum virtus admirabilis habeatur; et propter hoc sub certa constellatione advocati magis adveniunt."

54. Tomás De Aquino, S. Th., III, q. 42 a. 4 co.: "Unde et de sapientia dicitur, Prov. IX, quod misit ancillas suas vocare ad arcem. Sciendum tamen est, sicut Augustinus dicit, in I de Consens. Evang. aliquos gentiles existimasse Christum quosdam libros scripsisse continentes quaedam magica, quibus miracula faciebat, quae disciplina Christiana condemnat. Et tamen illi qui Christi libros tales se legisse affirmant, nulla talia faciunt qualia illum de libris tali-

Thémata. Revista de Filosofía №54 (2016) pp.: 149-174. 
[...] ellos no creían lo que los escritos de los apóstoles de Cristo, ni tampoco al mismo Cristo que escribiera lo que debiera creerse, y de [todo] ello opinaban que las artes mágicas hacían milagros. ${ }^{55}$

\section{Los modos de las artes mágicas con especial atención a la nigromancia}

Habiéndose sugerido la diferencia esencial entre los milagros y las prácticas mágicas, brevemente se hará alusión a la potencia de dichas artes demoníacas sobre la naturaleza. ${ }^{56}$ Para ello se darán a conocer algunos pasajes emblemáticos donde la magia puede ser aplicada, con el fin de destacar en particular las palabras del Aquinate sobre la magia concreta de la nigromancia.

Hasta el momento solo se ha mencionado que este arte oscuro puede emplearse sobre imágenes y anillos. Sin embargo el poder del mago, por potencia y permiso de los demonios, es extensivo a numerosísimas sustancias naturales.

Por consiguiente, es imposible que por virtud de los cuerpos celestes se mueva alguna cosa que por sí es inanimada. Sin embargo se dice que esto se hace mediante las artes mágicas, que, por ejemplo, alguna estatua se mueva por sí, o que emita alguna voz. No es, por lo tanto, posible que el efecto de las artes mágicas sea por virtud de los [cuerpos] celestes. ${ }^{57}$

Pero contra esto es que Agustín dice en el II libro De Doctrina Christiana que la superstición pertenece a los inútiles esfuerzos de las artes mágicas, y también los amuletos y los remedios que condena la medicina de los médicos, y los encantamientos y ciertas cifras que se llaman caracteres o cualquiera de las cosas que se llevan colgadas o atadas. ${ }^{58}$

bus fecisse mirantur."

55. Tomás de Aquino, S. Th., III, q. 42 a. 4 ad 3: "[...] quod illi qui Scripturae apostolorum de Christo credere nolunt, nec ipsi Christo scribenti credidissent, de quo opinabantur quod magicis artibus fecisset miracula."

56. No se insiste en todos los modos concretos de actividad mágica que menciona Tomás de Aquino. Algunos de ellos son explícitamente tratados por el Aquinate en la S. Th. como es el caso, por ejemplo, de la adivinación en consideración también con la influencia de los cuerpos celestes.

57. Tomás de Aquino, C. Gen., lib. 3 cap. 104 n. 7: "Impossibile est igitur fieri virtute caelestium corporum quod aliquod inanimatum per se moveatur. Fieri autem hoc per magicas artes dicitur, quod aliqua statua per se moveatur, aut vocem emittat. Non est ergo possibile quod effectus magicarum artium fiat virtute caelesti."

58. Tomás de Aquino, S. Th., II-II, q. 96 a. 2 s.c.: "Sed contra est quod Augustinus dicit, in II

Thémata. Revista de Filosofía ํ54 (2016) pp.: 149-174. 
Pero contra esto en Números XXII dice cierta Glosa que Balaam era divino, es decir Demonio por ministerio y por arte mágica pronosticaba algunas veces el futuro. Pero él mismo muchas veces preanunció verdades, según aquello que se lee en Números XXIV, que saldrá una estrella de Jacob y se levantará la vara de Israel. ${ }^{59}$

Debe considerarse que no parece absurdo, pese a que a algunos sí, que el alma estando separada del cuerpo padezca por fuego corporal, y que ello no es contra la naturaleza espiritual de la sustancia ligada al cuerpo. En efecto esto es hecho mediante la naturaleza, como es evidente en la unión del alma y del cuerpo, y por las artes mágicas, por las cuales algún espíritu está ligado a imágenes o anillos, o a otras cosas semejantes. ${ }^{60}$

\section{En torno al arte de la nigromancia los pasajes son muy pocos. En razón de ello se presenta una traducción de cada uno de ellos según un plausible orden de contenido. ${ }^{61}$}

Puesto que hay [efectivamente] aparición y locución a través de cadáveres. Y esta especie recibe el nombre de nigromancia, porque, como enseña Isidoro en [su] libro Etimologias, nigrum [negro, oscuro, sombrío] significa mortuus [muerte, consumación], y mantia designa adivinación, porque ciertos encantamientos, aplicados a la sangre, parecen resucitar a los muertos por adivinación y en respuesta a lo preguntado. En cambio las cosas futuras se preanuncian por hombres vivos, como se evidencia en los adivinos posesos por el demonio. ${ }^{62}$ Además, en el Itininerario de [san] Clemente

de Doct. Christ. quod ad superstitionem pertinent molimina magicarum artium, et ligaturae, et remedia quae medicorum quoque medicina condemnat, sive in praecantationibus, sive in quibusdam notis, quas characteres vocant, sive in quibuscumque rebus suspendendis atque insignandis."

59. Tomás de Aquino, S. Th., II-II, q. 172 a. 6 s.c.: "Sed contra est quod, Num. XXII, dicit quaedam Glossa quod Balaam divinus erat, Daemonum scilicet ministerio, et arte magica, nonnunquam futura praenoscebat. Sed ipse multa praenuntiavit vera, sicut est id quod habetur Num. XXIV, orietur stella ex Iacob, et consurget virga de Israel."

60. Tomás de Aquino, Comp. Th., lib. 1 cap. 180 co.: "Ne autem alicui absurdum videatur, animam a corpore separatam ab igne corporeo pati, considerandum est, non esse contra naturam spiritualis substantiae alligari corpori. Hoc enim et per naturam fit, sicut patet in unione animae ad corpus, et per magicas artes, per quas aliquis spiritus imaginibus aut anulis, aut aliquibus huiusmodi alligatur."

61. La razón de estas traducciones es en virtud de la cuasi-identificación entre la magia y la nigromancia. Esta última es una especie de aquella. Tomás no le dedica, a diferencia de otros modos de magia, un tratamiento directo. En respuesta a esta situación se presentan los siguientes pasajes, únicos en toda la obra de Tomás, en donde se aclara su confianza en los textos bíblicos y en la tradición teológica.

62. Tomás de Aquino, S. Th., II-II, q. 95 a. 3 co.: "Quandoque vero per mortuorum aliquorum apparitionem vel locutionem. Et haec species vocatur nigromantia, quia, ut Isidorus dicit, in libro Etymol. nigrum Graece mortuus, mantia divinatio nuncupatur, quia quibusdam praecantationibus, adhibito sanguine, videntur resuscitati mortui divinare et ad interrogata res-

Thémata. Revista de Filosofía №54 (2016) pp.: 149-174. 
se dice, según narra Niceta a Pedro, que Simón el Mago por artes mágicas retenía el alma de un niño al que había matado, y por ella ejercía operaciones mágicas. ${ }^{6}$

Jn XIV, 30: Viene el príncipe de este mundo y en Mi él [el espíritu de la maldad] no tiene lugar (quicquam), etc. Y por estos príncipes viene el Demonio con la sabiduría para los pueblos, a saber, la necromancia y las artes mágicas, y otras cosas de este modo. ${ }^{64}$

Y enseña [san] Jerónimo que se dice que [fue] por Apolinio Pytias por quien este género de artes mágicas se descubrió, por el cual parecen levantarse los muertos y predecir cosas futuras, como se lee en Reyes 1, 28. Rabano dice que es el nombre del espíritu maligno. ${ }^{65}$

Amós 3: Y se congregaron sobre los montes de Samaría y aparecieron numerosas insanías en medio de ellos. A esto pertenecen todas las vanas y nocivas supersticiones, como la nigromancia, la adivinación y los presagios. O bien, la insanía se dice propensión a la ira, a la riña y a los vanos espectáculos de los juegos. ${ }^{66}$

En efecto, no es contra la naturaleza reunir el espíritu con el cuerpo, como [cuando] observamos que el alma naturalmente se une al cuerpo en vistas a vivificarlo en sí mismo. Los demonios a través de la necromancia, también por potestad de los demonios superiores, amarran a algunos fantasmas [almas], o algunas otras cosas. De donde, en muchas artes mágicas los espíritus pueden sujetarse por poder divino al fuego corpóreo, no como si dieran vida, sino como recibiendo castigo, según dice Agustín. Pero porque aquello que es de menor virtud no puede por su fuerza ligarse a aquello que es de mayor virtud, entonces [se sigue] que ningún cuerpo pueda unirse a ningún espíritu sino es por una cierta virtud superior. Y a causa de esto se dice que el fuego corpóreo agita al alma separada no por virtud propia, sino en cuanto es instrumento del castigo dado por la divina justicia. ${ }^{67}$

pondere. Quandoque vero futura praenuntiant per homines vivos, sicut in arreptitiis patet." 63. Tomás de Aquino, S. Th., I, q. 117 a. 4 arg. 2: "Praeterea, in itinerario Clementis dicitur, narrante Niceta ad Petrum, quod Simon magus per magicas artes pueri a se interfecti animam retinebat, per quam magicas operationes efficiebat."

64. Tomás de Aquino, Io. XIV, 30: "venit princeps mundi huius, et in me non habet quicquam, etc. Et ab his principibus venit sapientia culturae Daemonum, scilicet necromantia, et magicae artes, et huiusmodi."

65. Tomás de Aquino, Sup. Isaiam, cap. 8 1. 4: "Et dicit Hieronymus, quod dicuntur ab Apolline Pythio, quia hoc genus artis magicae invenit, per quod videntur mortui suscitari, et de futuris aliqua praedicere: sicut legitur 1 Reg. 28. Rabanus dicit, quod est nomen maligni spiritus."

66. Tomás de Aquino, Amos 3: "congregamini super montes Samariae, et videte insanias multas in medio ejus. Ad hanc pertinent omnes vanae et noxiae superstitiones, sicut nigromantia, divinationes, et auguria. Vel insania dicitur iracundia, rixa, vel vana spectacula ludorum."

67. Tomás de Aquino, Quodlibet II, q. 7 a. 1 co.: "Non enim hoc est contra naturam spiritus corpori alligari, cum videamus animam naturaliter alligari corpori ad vivificandum ipsum. Daemones etiam per necromantiam potestate superiorum Daemonum alligantur aliquibus imaginibus, vel aliquibus aliis rebus; unde multo magis possunt spiritus alligari divina vir- 


\section{Consideraciones finales}

En relación con la noción de ciencia/arte de la magia se ha querido subrayar la importancia que le otorga Tomás de Aquino en el marco de las ciencias en general, llevando a cabo un relevamiento y una exégesis de este término en su opera omnia. La presentación del mentado arte ha tenido la intención de propiciar un conocimiento directo y total de la comprensión que tenía este fraile dominico. Un saber que se fundamenta más en la tradición ${ }^{68}$ que en aquello que explícitamente se afirma. Empero, con ello se ha logrado poner de manifiesto una visión de conjunto sobre la magia, y en razón de esta situación, se valora, ahora sí, la escasa originalidad de Tomás y su confianza casi indiscutida en la tradición teológica. Sin embargo, si se atiende al marco en el que están insertos tales pasajes sobre magia, destaca la autenticidad del pensamiento de Aquino en razón de su particular asunción del sistema aristotélico de las ciencias que aquí aparece sólo esbozado. Asumida la magia bajo esta perspectiva, se evidencia que la teología estudia la naturaleza metafísica buena ${ }^{69}$ de los ángeles y su comportamiento ético, que para los demonios es malevolencia pura (pues una vez confirmados en la maldad no pueden arrepentirse).

La inmoralidad de los ángeles caídos, por la poderosa sugestión que pueden operar, provocan una retorsión espiritual en los hombres. En el caso de los magos es particularmente manifiesto, pues la seducción de los demonios infesta la mente -que tiende naturalmente hacia Dios según que él la ilumina- y compromete su voluntad, la que hace las veces de instrumento -y en ello involucra al hombre entero- para ejecutar maleficios,

tute igni corporeo, non ut dent vitam, sed ut accipiant poenam, sicut Augustinus dicit. Sed quia quod est minoris virtutis, non potest sua virtute ligare id quod est maioris virtutis; inde est quod nullum corpus potest ligare spiritum, qui est maioris virtutis, nisi aliqua superiori virtute; et propter hoc dicitur, quod ignis corporeus agit in animam separatam non virtute propria, sed in quantum est instrumentum divinae iustitiae vindicantis."

68. Un ejemplo de ello puede verse en, Tomás De Aquino, S. Th., I-II, q. 102 a. 6 ad 5: "[...] quod gentiles fructus primitivos, quos fortunatos aestimabant, diis suis offerebant, vel etiam comburebant eos ad quaedam magica facienda. Et ideo praeceptum est eis ut fructus trium primorum annorum immundos reputarent." Cfr. Tomás de Aquino, De pot., q. 6 a. 10 ad 3: "[...] quod si Salomon exorcismos suos eo tempore fecit quando erat in statu salutis, potuit esse in illis exorcismis vis cogendi Daemones ex virtute divina."

69. En efecto, los demonios son ángeles cuya naturaleza siempre es buena. Sólo su acción, aquella de su caída moral, y su constante afirmación en ella, es mala. De allí que no exista para Tomás una naturaleza metafísica per se mala. A esto se refieren los siguientes pasajes. Cfr. Tomás de Aquino, C. Gen., lib. 3 cap. 107 n. 1: "Non est autem possibile quod sit naturalis malitia in substantiis intelligentibus quarum auxilio magicae artes operantur." Cfr. TomÁs DE Aquino, C. Gen., lib. 3 cap. 107 n. 7: "Naturali igitur ordine substantia intellectualis vult bonum. Impossibile est igitur quod illae substantiae intellectuales quarum auxilio magicae artes utuntur, sint naturaliter malae."

Thémata. Revista de Filosofía №54 (2016) pp.: 149-174. 
levantamiento de muertos, y otras operaciones varias en las que el demonio - habiendose también negado libremente la búqueda de la beatitud por parte de los hombres- opera transformando, limitadamente, la naturaleza física. ${ }^{70}$ Este singular acontecimiento manifiesta la oscuridad que nubla la inteligencia en los razonamientos, desarticulando fuertemente la jerarquía quoad nos de las ciencias que testifica sobre los estratos de la naturaleza y, de modo especial, la presencia de Dios en los mismos. Trocada la beatitud por maldad y la studiositas por curiositas, se colocan las bases propicias, aunque de suyo insuficientes, que inclinan al hombre a experimentar eventos demoníacos.

\section{Referencias bibliográficas}

Bazán Díaz, I.: "El mundo de las supersticiones y el paso de la hechicería a la brujomanía en Euskal-Herria (Siglos XIII al XVI)" en Vasconia, n. 25, 1998, p. 103-133.

Cardini, F.: Magia, Brujería y Superstición en el Occidente medieval. Barcelona: Península, 1999.

Equivard, J.-B.: Une introduction à la philosophie. Les proèmes des lectures de saint Thomas d'Aquin aux oevres principales d'Aristote, L'esprit des disciplines fondamentales (1). Paris: F.-X. de Guibert, 2004.

Feyerabend, P. K.: ¿ Por qué no Platón? Madrid: Técnos, 1982.

Feyerabend, P. K.: "La ética como medida de la verdad científica", en Provocaciones filosóficas. Madrid: Biblioteca Nueva, 2003.

Giralt, S.: "Magia y ciencia en la Baja Edad Media: la construcción de los límites entre la magia natural y la nigromancia, c. 1230 - c. 1310 ” en Clio y Crimen, n. 8, 2011, pp. 13-72.

Magnavacca, S.: Léxico técnico de filosofía medieval. Buenos Aires: Miño y Dávila, 1995.

Martínez, E.: "Bonum amatur inquantum es communicabile amanti. Amor y bien en la metafísica de santo Tomás de Aquino", Espíritu, LXI, n. 143, 2012, pp. 73-93.

Mendoza, J. M. F.: "Artes liberales y serviles en Tomás de Aquino: doctrina y división de las mismas (parte I)", Analogía Filosófica, vol. XXVIII, n. 2, 2014, pp. 3-23.

70. Los demonios no fueron privados de su ciencia y poder en lo tocante a su rango espiritual o naturaleza metafísica. De allí que ellos puedan ejercer actos mágicos. Cfr. TomÁs DE AQUINo, Sup. Sent., lib. 2 d. 7 q. 1 pr.: "[...] quod ergo Hieronymus ait... accipi oportet secundum statum in quo creata sunt. Quorum scientia atque virtute etiam magicae artes exercentur."

Thémata. Revista de Filosofía №54 (2016) pp.: 149-174. 
Mendoza, J. M. F.: "Cartografía epistémica concebida por Tomás de Aquino según su interpretación de las obras aristotélicas”, Tópicos, n. 39, 2010, pp. 131-155.

Mendoza, J. M. F.: "Breve status quaestionis de la ciencia neotomista como introducción confusa al sentido de scientia tomística: algunas apreciaciones históricas en filósofos del siglo XX", Pensamiento, vol. 71, n. 267, 2015, pp. 617-630.

Mérida Jiménez, R. M.: Fuera de la orden de natura: magias, milagros y maravillas en el Amdis de Gaula. Berlin: Ed. Reichenberger, 2001.

Olivares Bøgeskov, B.: "Sabiduría, felicidad y perfección: relación entre el conocimiento teórico y la bondad moral del fin último y la felicidad en el pensamiento de santo Tomás", Espíritu, LXII, n. 145, 2013, pp. 73-93.

Tomás de Aquino, Scriptum super Sententiis, http://www.corpusthomisticum.org/iopera.html

Tomás de Aquino, Summa contra Gentiles, http://www.corpusthomisticum.org/iopera.html

Tomás de Aquino, Summa Theologiae, http://www.corpusthomisticum.org/iopera.html

Tomás de Aquino, Quaestiones disputatae de veritate 1, http:// www.corpusthomisticum.org/iopera.html

Tomás de Aquino, Quaestiones disputatae de veritate 2, http:// www.corpusthomisticum.org/iopera.html

Tomás de Aquino, Quaestiones disputatae de potentia 6, http:// www.corpusthomisticum.org/iopera.html

Tomás de Aquino, Quaestio disputata de anima, http://www.corpusthomisticum.org/iopera.html

Tomás de Aquino, Quaestiones disputatae de malo 16, http://www. corpusthomisticum.org/iopera.html

Tomás de Aquino, Quodlibet IV, http://www.corpusthomisticum. org/iopera.html

Tomás de Aquino, Quodlibet II, http://www.corpusthomisticum. org/iopera.html

Tomás de Aquino, Compendium theologiae, http://www.corpusthomisticum.org/iopera.html

Tomás de Aquino, De operationibus occultis naturae, http://www. corpusthomisticum.org/iopera.html

Tomás de Aquino, Commentaria in octo libros Physicorum, http:// www.corpusthomisticum.org/iopera.html

Tomás de Aquino, In libros Aristotelis De caelo et mundo expositio, http://www.corpusthomisticum.org/iopera.html

Tomás de Aquino, In librum Aristotelis De generatione et corruptione expositio, http://www.corpusthomisticum.org/iopera.html 
Tomás de Aquino, Sentencia libri De sensu et sensato, http://www. corpusthomisticum.org/iopera.html

Tomás de Aquino, Sententia libri Metaphysicae, http://www.corpusthomisticum.org/iopera.html

Tomás de Aquino, Super Boetium De Trinitate, http://www.corpusthomisticum.org/iopera.html

Tomás de Aquino, Catena aurea in quatuor Evangelia Expositio in Matthaeum, http://www.corpusthomisticum.org/iopera.html

Tomás de Aquino, Catena aurea in quatuor Evangelia Expositio in Lucam, http://www.corpusthomisticum.org/iopera.html

Tomás de Aquino, Super Epistolam B. Pauli ad Galatas lectura, http://www.corpusthomisticum.org/iopera.html

Tomás de Aquino, Expositio super Isaiam ad litteram, http://www. corpusthomisticum.org/iopera.html

Tomás de Aquino, Super Evangelium S. Ioannis lectura, http:// www.corpusthomisticum.org/iopera.html

Pasqua, H.: "La vision béatifique selon saint Thomas d'Aquin et Dietrich de Freiberg", R.T., n. CXII, 2012, pp. 513-527.

Vázquez Ramos, D.: La virtud de la studiositas y el conocimiento. Un estudio desde Tomás de Aquino. Pamplona: Eunsa, 2009. 